Semarang

State University

Undergraduate

LAWE

SOCIETY

REVIEW

VOLUME 1 ISSUE 2, JULY 2021
ISSN (Print): 2807-8225 ISSN (Online): 2807-8683

History of Article

Submitted: December 2020

Revised: March 2021

Accepted: May 2021

How to cite:

Abdullah, R. A. R. (2021). Ethics and Legal Issues in the Abortion Case. Semarang State University Undergraduate Law and Society Review, 1(2), 175-190. https://doi.org/10.15294/lsr.v1i2.50547

(c) 2021 Authors. This work is licensed under a AttributionNonCommercial-ShareAlike 4.0 International (CC BY-NC-SA 4.0). All writings published in this journal are personal views of the authors and do not represent the views of this journal and the author's affiliated institutions.

\title{
Ethics and Legal Issues in the Abortion Case
}

\author{
Rizki Aji Rahmawan ABDULLAH® \\ Faculty of Law, Universitas Negeri Semarang \\ Jl. Taman Siswa, Sekaran, Gunungpati, Semarang \\ Jawa Tengah, INDONESIA \\ 凹rizkirahmawan147@gmail.com
}

\begin{abstract}
In Indonesia regulated in Law No. 36 of 2009 on health. Any person who deliberately performs an abortion is inconsistent with the provisions referred to in Article 75 paragraph (2) shall be punished with imprisonment of not more than 10 (ten) years and a maximum fine of Rp.1.000.000.000,00 (one billion rupiah). Basically, the treatment of abortion is found in them in life. Some of the driving forces for abortion are quite numerous and the abortion treatment can be viewed in any perspective. One thing that is commonplace among today is such an unwanted pregnancy because of a factor and aims to disrupt the pregnancy by an act of abortion. But the act of abortion is not roughly done deliberately but the existence of an unwanted so that the act of abortion
\end{abstract}


should be done. The notion of abortion of the womb, the fetal exclusion is not appropriate in time whether it is intentional or not.

KEYWORDS. Abortion; Legal Aspects; Moral; Ethics

\section{INTRODUCTION}

Abortion according to Indonesian dictionary means abortion. There is also the word abortion taken from the English abortion derived from the Latin which means abortion or fetal abortion from the womb before he was able to live alone, ie in the first 28 weeks of pregnancy. In general, abortion is abortion of the womb, the fetal exclusion is not appropriate in time either intentional or unintentional. Usually done when the fetus is still young before the fourth month of pregnancy. Medically, abortion is the end or fall of pregnancy before the womb reaches the age of 20 weeks. According to legal terms, abortion is the to stop of pregnancy or death of the fetus before the time of birth.

The problem of Abortion is highly controversial as a matter of debate. Actually, the act of abortion is seen from the classification of evil, that the killing of fetal killing is not in the category of whole human killing but is still an act of sin and sin. The debate over abortion continues to emerge in the community, yet there is no common ground on it. The problem of abortion is not only related to health issues but also closely with morals, religion and law. The view for the community of abortion is very embarrassing, as if the person doing the abortion has no good morals. Seeing the positive law in Indonesia, everyone is prohibited from abortion, the prohibition is contained in Article 75 paragraph (1) of Law no. 36 of 2009 on health.

Based on that description, the problem of abortion in general is considered by most of the community as a crime. But not all abortion 
actions can be said to be criminal if there is no clear evidence. Abortion can be divided into two namely:

1) With medical reason to save the life / health of the mother and often also called abortus provocatus therapeuticus or abortus provocatus medicinalis;

2) For other reasons and called abortus provocatus criminalis.

The abortion can also occur due to human actions or scientific causes. Though It should, Abortion should only be done for medical action with the intention of saving the life of a mother who was poisoned during pregnancy. Much has been the view that abortion is a victim of an unwanted pregnancy or pregnancy so as to perform an abortion with medical indications so that an abortion due to a maternal physical disorder may also threaten the mother's life.

From the laws and regulations applicable in Indonesia, the right to abortion is legally justified if done because of medical reasons or considerations or medical emergencies if done not in conflict with law and religion.

The juridical approach, in the 1945 Constitution of article 28 A written "to live and preserve life and life" it is clear that the unborn fetus is entitled to live and enjoy the world. According to Indonesian law, Abortion is still included as a crime. The following articles contained in the Criminal Code include:

Article 299

1) Anyone who deliberately treats a woman or orders to be treated, informed or indicted of hope, that because the treatment is pregnant can be aborted, threatened with a maximum imprisonment of four years or a fine of not more than forty thousand rupiah

2) If the offender, doing so for profit, or making such act as a livelihood or habit or if he is a physician, midwife or medicine, his pen can be added by one third 
3) If the guilty person commits the crime in carrying out the livelihood, then it can be deprived of his right to make a living.

Article 346

A woman who deliberately abort or kill her womb or send another person to, is threatened with a maximum imprisonment of four years

Article 347

1) Anyone who intentionally abort or kill a woman's content without consent is threatened with a maximum imprisonment of twelve years

2) If the act caused the woman, it shall be criminal at the latest fifteen years.

Article 348

1) Anyone who intentionally abort or disable a woman's consent with his / her consent, shall be punished with imprisonment of six months

2) If the act resulted in the death of the woman, due to imprisonment of not more than seven years.

Article 349

If a physician, midwife or interpreter assisted in committing the crime referred to in article 346 or committed any of the abuses described in articles 347 and 348, then the penalty prescribed in that article may be supplemented by one-third and may be deprived of the right to conduct the livelihood in which the crime is committed.

Article 535

Any person who expressly expresses a suggestion for abortion, whether or not he is openly or unasked offering, or openly or by broadcasting unsolicited writing, pointing out as to be able, such means or mediation, is threatened with the 
most confinement three months or a fine of four thousand five hundred rupiah.

\section{CRIMINAL LAW ARRANGEMENT AGAINST CRIMINAL ABORTION IN INDONESIA}

Basically, the problem of frequent abortion has included criminal acts or criminal acts can be seen in the Criminal Code Even though Law No. 36 of 2009 contains sanctions against the act of abortion. In addition to Crime and offenses, one set forth in the Criminal Code is a matter of criminal Abortion. The provisions of criminal abortion can be seen in chapter XIV of the second book of the Criminal Code on evil against life. Especially in chapters 346 349.

There is no explanation on the definition of this content in the Criminal Code and does not detail the meaning of abortion and killing the contents. Thus, the Criminal Code only regulates the abortion of provocatus criminalis, in which all types of abortion are prohibited and are not permitted by law whatever the reason, this arrangement in the Criminal Code which is a Dutch heritage directly contrary to the legal basis and politics is "Protect all the Indonesian nation and to promote general welfare based on Pancasila and of the 1945 Constitution for prohibiting unconventional abortion of provcatus. "It is very burdensome medical who are forced to have provocatus abortion to save the lives of mothers who during this is an exception outside the legislation. It is therefore necessary for a new legislation that contains aspects of legal constriction for medical workers in performing their obligations. In this case the new regulatory compliance is fulfilled in Law No. 36 of 2009 on the health of substitution of Act No. 23 of 1992. The substitute law allows for provocatus medicalist abortion with therapeucatical specification. Thus article 75 of Law no. 36 of 2009 which regulates the medicalist provocatus abortion can still be valid 
in Indonesia although the rules are different from the provocatus criminalis abortion formula according to the Criminal Code.

See the formulation of article 75 of Law no. 36 of 2009 it is clear that Law no. 36 of 2009 prohibits abortion except the type of abortion provocatus therapeauticus (abortion performed to save the life of the mother or fetus). Based on the description, it can be concluded that Article 75 of Law no. 36 Year 2009 on health regulates the provocatus abortion that is permitted in Indonesia namely provocatus abortion for medical indication or also known as provocatus medicalis abortion.In formulating the punishment, the lawmakers only give maximum limit, which is maximum of 10 years in prison and a fine of at most Rp.1.000.000.000, - (One billion rupiah).

In the world of medical doctors there are three kinds of abortion, one of them is Spontaneous or natural abortion that takes place without any action. Mostly due to poor quality of eggs and sperm cells. The Ulama agree there is no problem in this case because it occurs naturally and by the will of Allah. The type of spontaneous abortion can be differentiated according to the condition as follows:

1) Abortus Incipient

In this type of abortion pregnancy cannot be ordered again so the treatment is only aimed at stopping the bleeding and cleaning the uterine cavity from the rest of the conception.

2) Complete Abortion

In this case, all the results of the conspiracy are issued. Abortus incompletus, in this abortion the content is out and more delayed in the stomach, so the treatment aims to stop the bleeding and clean the uterine cavity from the side of the conception.

3) Habitual Abortus

In this type of miscarriage occurs three times or more in a row. The cause of this miscarriage is the presence of abnormalities in the cervix or swelling of the womb or congenital defects. 
4) Abortion Imminence

In this type of pregnancy can still be maintained for example with rest and drug administration.

5) Artificial or deliberate Abortion, or Abortus Provocatus Criminalis

Termination of pregnancy before 20 weeks' gestation or fetal weight is less than 500 grams as a result of deliberate action and is based on both the mother and the abortion (in this case the doctor, the midwife).

6) Provocatus Therapeuticum Abortion

Abortion of artificial contents that are performed on medical indications. For example, a mother is pregnant with chronic high blood pressure, severe heart disease or shortness of breath that can harm the mother and fetus in the womb.

With so many ways that can be taken to abortion (Abortion). The most traditional way is in a rough and hard way, like massaging a certain part, namely the belly and hip of the body of a woman who will be aborted kannnya. Another way is to take traditional medicine or ingredients by swallowing through the mouth or put into the vagina, and there is also a way to apply a substance that pores the skin on the abdomen, or the mother deliberately hungry for the fetus to die.

In the treatment of acts of abortion there must be cause or driving factor to pass the abortion, can be seen the factors that result in abortion act as follows:

1) On the basis of medical indications: to nourish / mother's life.

2) On the basis of social indications: pregnancy outside marriage, rape, economic difficulties, contraceptive failure when not wanting to get pregnant, career choice, and gender choice.

The likely impacts of abortion are:

1) Inflammation of the wound and infection of the genitalia wall and damage to nearby organs.

2) Tear the inner cervix 
3) The uterine wall can be translucent

4) Bleeding

5) Infection

The World Health Organization estimates that worldwide there are 20 million cases of unsafe abortion, $13 \%$ ending in death. In ASEAN, 2,800,000 cases of abortion, or $15 \%$ of women die from unsafe abortions. WHO estimates that of the 200 million pregnancies per year in the world around $38 \%$ (75 million) is an unwanted pregnancy? $11 \%$ (8 million) of them due to contraceptive failure while the rest because they do not use contraception. Of the 75 women who had an unwanted pregnancy, two-thirds would end their pregnancies with intentional abortions and about 60\% (30 million) performed safely with the help of professionals. While the remaining $40 \%$ (20 million) done unsafe by personnel who are not competent.

\section{ABORTION IN PERSPECTIVE FIQH AND ISLAMIC LAW}

Maria Ulfah Anshor's study of some fiqh literature shows that abortion in fikh perspectives can be classified into 5 categories, namely:

1) Spontaneous abortion; natural abortion that occurs without any cause / influence from outside or with other languages fall by itself.

2) Abortion due to emergency or treatment, this type of abortion is an abortion done because there are physical reasons that threaten the safety of the mother when her pregnancy is continued.

3) Abortion by mistake, this abortion occurs without intentional elements, without intending to abort the contents but occurs.

4) Abortion is intentional. 
5) Abortion deliberately, Abortion is done with the intention to abort the content by way of consonant food or drink or by certain actions that result in miscarriage.

When examined more deeply, the categorization of clerics regarding abortion tends to use a physical approach, with measurable and measurable measures. While psychic indicators are not adequately discussed by scholars.

In relation to the way the perpetrator performs an abortion, in this perspective the usual way of carrying the risk is high enough if done not according to the standard of the medical profession. How abortion actions are performed as follows:

1) The action itself; usually done as a result of unproductive pregnancy by making some attempts to abort the content based on the reading and knowledge gained.

2) Using the help of others, such as:

a. Shaman; Traditional abortion relief can be very diverse. The most common way is done with physical manipulation, namely by doing a massage on the womb to remove the fetus with extraordinary pain effects. This action is usually modified with a herb or in some cases with the help of magic.

b. Acupuncture; acupuncture techniques can also shed menstruation.

c. Doctor's actions; in general, midwives or doctors perform abortion injections by injection. If this does not work, new curettage or siphoning is used. At the age of 1-3 months, the body part of the fetus that has been formed is destroyed with abortion (cunan abortus). For further gestational age, (3-6 months) when the fetus has fully grown its physical member with the existing nerve functioning, the fetus is killed first in the uterus with fluid, to be remove. 


\section{ABORTION ON LEGAL, ETHICS, AND MORAL ASPECTS: AN INDONESIAN INSIGHT}

In daily life analyzing abortion is a criminal act but not all abortion can be categorized as a criminal act but not all abortion acts are actions that there are legalized abortions in Indonesia. In the legislation in Indonesia abortion is divided into two namely:

1) For medical reasons to save the life or health of the mother and often referred to as abortus provocatus therapeuticus or abortus provocatus medicinalis;

2) For other reasons and called abortus provocatus criminalis.

In addition to the Act Number 23 of 1992 on health that regulates the abortion are still many other legislation that regulate the abortion, among others:

1) Law Number 1 Year 1946 on the Criminal Code (KUHP);

2) Law Number 39 Year 1999 on Human Rights (HAM);

3) Law Number 36 Year 2009 on Health;

4) Government Regulation No. 26 of 2014 on Reproductive Health.

The moral order arises in ancient Greek societies associated with the religious conception of logos, ie the divine mind of money guides people to a worthy life. Moral existence in law, still felt as a necessity to this day. Every tragedy or humanitarian problem, always requires a moral legal solution. In short the moral law is a necessity for human beings. Without a moral law, no developed society will survive in residence and justice. Law can be blamed as a morally bad thing simply because it requires people to do actions that are forbidden by morality, or because it requires people not to do things that are morally obligated. Here are two related difficulties, namely, that the words 'morality' and all other terms that are related or almost synonymous like ethics, have a large area or 'open texture'. 
All moral orders have only one thing in common: they are social norms, those that reflect certain behaviors, directly or indirectly from one human to another. All moral systems have one thing in common, that is, the 'supposed' moral systems are something and have a normative character. What is good that is morally good is what is in keeping with the social morals that define a particular human behavior. Between law on the one hand with the values of social culture on the other hand there is a close relationship. The close connection between the law and socio-cultural values of the community is that the bad law is nothing but a law that reflects the value of the value that exists in society. So that in each norm is applied directly to the community, until now. The will of good behavior toward humans leads to an association of persons based on rational and moral principles. This is done by make system of norms that must be adhered to people belonging to certain communities.

The difference in norms concerns both the basic norm (subjectiveobjective) nor the weight of the subjective moral norm, because it is related to the conscience of the subject, again demanding to be truly obeyed. While the objective, because of its relation to the state, but demands to be obeyed as well. The behavior of each community will certainly be seen from its actions, whether in the act according to the existing norm or not. Inner morals will be ashamed if what they do violate the order of life in society as an act of abortion.

Abortion or abortion under criminal law, which is a crime committed with an act that results in a prematurely born birth content according to nature. The crime of abortion is also referred to as the murder of the child who is planning, where in the abortion of the content there must be a vrucht or a living (kind) which is then switched off. This equation also causes the crime of abortion (abortus) is included in the book title II of the Criminal Code on crimes against the lives of people. Legal foundations (clauses) that govern abortion, including KUHP CHAPTER XIV, crime against morality, article 281 verse (1). In paragraph (2) shall be punishable by imprisonment of a maximum of nine months or a fine of not more than $\operatorname{Rp} 9000,-$, whoever 
offers, grants to continue or temporarily, submits or displays inscriptions, images or objects in violation of decency, prevent or abort.

Furtheremore, Abortion has been done by humans since centuries ago, but at that time there is no law that regulates the act of abortion. Regulations on abortion began in $4 \mathrm{AD}$, so there has been a ban on abortion since then. The law on abortion is improving as the revolution in public attitudes and governments work together to convey aspirations in various worlds against abortion.

In Indonesia, the regulations on abortion, one of which is contained in the Indonesian Criminal Code chapter XIV concerning the crime of morality Article 299 paragraph (1) stated that: A deliberate act of abortion on one's own behest or appeals to another is considered a criminal act that is threatened with the law maximum 4 years imprisonment or a fine of at most three thousand rupiah.

Paragraph (2) states: If the abortion is an outsider (not a pregnant mother) and the action is performed for economic purposes, as a livelihood, the penalty may be increased by one third of the sentence in paragraph (1) above and if so long this is done as a livelihood. In addition, Criminal Code Chapter XVIII on Crimes Against People's Freedom, article 346 explains that: A woman who deliberately abort or kill her womb or send someone else for it, is threatened with a maximum imprisonment of four years.

In article 347: Anyone with any abortion or death of a woman without her consent is punishable by imprisonment for a maximum of twelve years. If the act resulted in the death of the woman, threatened with imprisonment of fifteen years at the most. And in Article 348: About a person who commits a murder or kills the contents with the woman's consent, is punishable by a maximum imprisonment of five years and six months, if the act resulted in the woman's death, sentenced to imprisonment of a maximum of seven years.

Subsequently Article 349 stipulates: If the offender of Article 346, 347 and 348 is a doctor, midwife or shaman, then his penalty shall be added by 
one third and may be revoked of his right to conduct a search in which the crime is committed.

\section{CONCLUSION}

In general, the act of abortion is done because of a strong driving factor, so that action must be done. In such behavior there is a different perspective or perspective in presenting the problem. It has been explained that not all abortion acts are evil even though they do not kill the whole person but are still evil and sinful. Abortion act has been regulated in Article 75 of Law Number 36 Year 2009 concerning Health. The Article has been described as a violation and punishment provision for those committing an act of abortion. But it has also been explained that the abortion is not criminalized if it is in accordance with medical provisions such as provocatus medicalis abortion and provocatus therapeuticus abortion in accordance with medical provisions, aiming to save the mother's life then no offense can be punished. Law Number 36 Year 2009 is a renewal of the previous law that is Act No. 23 of 1992 regulation changes to improve or improve things that are not in accordance with some provisions. Many kinds of abortions are categorized but some of these abortions are not legal or are still illegal in the act of abortion.

\section{REFERENCES}

Anshor Maria Ulfah. Fikih Aborsi, hlm.38-40.

Dasuki Hafizh. Ensiklopedia Islam, Ihtiar Baru van Houve, 1994, hlm.33.

Hart, H.L.A. Konsep Hukum, Nusa Media, Bandung, 2013, hlm.260.

Huijbers, Theo. Filsafat Hukum, Kanisius, Yogyakarta, 1995, hlm.64-65.

Ibrahim Mohsin, Abul Fadol, terjemah, Sari Meutia. Aborsi, Kontrasepsi dan mengatasi kemandulan, Mizan, Bandung, 1997, hlm.125.

Kelsen, Hans. Teori Hukum Murni, Nusa Media, Bandung, 2015, hlm.74-75. 
Komalawati D. Veronica. Hukum dan Etika Dalam Prakter Dokter, Pustaka Sinar Harapan, Jakarta, 1989, hlm.64.

Kontroversi dibalik upaya penghentian kehamilan, dalam Medika Jurnal Kedokteran dan Farmasi, No. 2 Tahun XXIII, Februari 1957, hlm. 158163.

Kumpulan Kitab Undang-Undang Hukum: KUH Perdata, KUHP, KUHAP, WIPRESS, Jakarta, 2008, hlm.507-508

Mangesti, Yovita A. Dan Bernard L. Tanya. Moralitas Hukum, Genta Publishing, Yogyakarta, 2014, hlm.25.

Munawir Ahmad Anees. Islam dan Masa Depan Biologis Manusia, Mizan, Bandung, 1991, hlm.35.

Musyarofa Ita. Wacana Hak Asasi Manusia Dalam Perdebatan Aborsi, Dalam Jurnal Studi Gender Indonesia Vol. 02, No. 01 Agustus 2011, hlm.37

Prent. K, C. M. J. Adisubrata, WJS. Poerwadarminta. Kamus Latin Indonesia, Kanisius, Yogyakarta, 1962, hlm.2.

Rasjidi, Lili. Dasar-Dasar Filsafat Hukum, Citra Aditya Bakti, Bandung, 1990, hlm.58.

Setiady Tolib. Pokok-Pokok Ilmu Kedokteran Kehakiman, Alfabeta, Bandung, 2009, hlm.176-177.

Soekanto Soerjono dan Sri Mamudji. Pengantar Hukum Normatif, Rajawali, Jakarta, 1985, hlm.14.

Soekanto Soerjono. Metode Penelitian Hukum, UI Press, Jakarta, 2007, hlm.257.

Soekanto Soerjono. Pengantar Penelitian Hukum, Penerbit Universitas Indonesia, Jakarta, 2001, hlm.9-10.

Temuan Penelitian Atas Hendartini Habsjah, dalam Maria Ulfah Anshor. Aborsi, hlm.192-204.

Utari, Indah Sri. Pengantar Filsafat Hukum, Sarnu Untung, Grobogan, 2017, hlm.81. 
I feel the greatest destroyer of peace today is 'Abortion', because it is a war against the child... A direct killing of the innocent child, 'Murder' by the mother herself... And if we can accept that a mother can kill even her own child, how can we tell other people not to kill one another? How do we persuade a woman not to have an abortion? As always, we must persuade her with love... And we remind ourselves that love means to be willing to give until it hurts...

\section{Mother Teresa}




\section{Conflicting Interest Statement}

All authors declared that there is no potential conflict of interest on publishing this article.

\section{Funding}

None

\section{Publishing Ethical and Originality Statement}

All authors declared that this work is original and has never been published in any form and in any media, nor is it under consideration for publication in any journal, and all sources cited in this work refer to the basic standards of scientific citation. 